\title{
Additional abdominal measurements are a useful tool to evaluate body composition in obese women
}

\author{
Andresa de Toledo TRIFFONI-MEL01', Flávia de Andrade MONTE-ALEGRE², \\ Vania Aparecida LEANDRO-MERHI ${ }^{3}$ and Rosa Wanda DIEZ-GARCIA ${ }^{4}$
}

Received 31/3/2019

Accepted 18/6/2019

\begin{abstract}
Background - During weight gain, most of the excess adipose tissue accumulates in the trunk. This alters the body shape and makes collection of anthropometric measurements, especially waist circumference (WC), difficult. Objective - To evaluate the sensitivity and applicability of additional abdominal measurements in order to assess body composition of obese women. Methods - A total of 30 women between 20 and 50 years of age and BMI above $30 \mathrm{~kg} / \mathrm{m}^{2}$ were assessed. Three WC measurements, were performed: at the umbilical scar designated as WC1 and at 8 and $16 \mathrm{~cm}$ above the umbilical scar, designated as WC2, and WC3 respectively. The correlation ( $\mathrm{r}$ ) between these anthropometric measurements and their sum was assessed against the parameters fat mass (FM), free fat mass (FFM), body fat percentage (\%BF), and trunk fat percentage $(\% \mathrm{TF})$, obtained by total and trunk segmental bioelectric impedance analysis (BIA) as well as by the golden standard total and trunk dual energy X-ray absorptiometry (DXA). Results - The measurements WC1, WC2, WC3, and their sum correlated strongly and moderately with the parameters FM, FFM, and \%BF in total BIA and in both total DXA and trunk DXA. Conclusion - The results demonstrated a robust correlation between the sum of the three WC measurements and total and trunk DXA in obese women suggesting that such measurements may be a good indicator of body and trunk fat in women, actually superior to BIA results. The use of these three measurements may be an alternative for the assessment of body and trunk fat, in those cases in which the body shape due to adipose tissue trunk accumulation makes accurate classical measurement (WC1) difficult.
\end{abstract}

HEADINGS - Obesity. Women. Abdominal circumference. Body composition. Photon absorptiometry. Abdomen. Dimensional measurement accuracy. Electric impedance.

\section{INTRODUCTION}

The prevalence of severe obesity has increased in western countries $^{(1)}$. Excess adipose tissue accumulation culminates in enlarged waist circumference ${ }^{(2)}$, which is a consequence of any weight gain. Indeed, Wang et al. ${ }^{(3)}$ reported that fat accumulates mainly in the trunk, regardless of the body mass index (BMI). There are many methods to evaluate the body composition, but it is challenging in the obese people ${ }^{(4)}$. The bioelectrical impedance analysis method for body composition assessment in the severely obese people is limited by the lack of population specific equations; it gives a rough estimate of total body adipose tissue share ${ }^{(5)}$. Underwater weighing, which is based on the different densities of adipose tissue and lean tissue, is assumed to be the gold standard for determination of percent body fat ${ }^{(5)}$. Discomfort, apprehension about being tested in the water tank, inability to perform the maneuvers required for satisfactory testing are common problems with this test in obese people ${ }^{(4)}$. Imaging techniques used to quantify adipose tissue are magnetic resonance imaging, computerized tomography and dual energy X-ray absorptiometry (DXA) ${ }^{(5)}$. Magnetic resonance imaging is useful for severely obese people, because the radio frequency used can penetrate large amount of adipose tissue ${ }^{(4)}$. However, a limitation of magnetic resonance for examination of obese subjects is the relatively small open bore of the imagers, which is about 60 $\mathrm{cm}$ for most of the devices ${ }^{(5)}$. Computerized tomography also is used to determine body fat distribution in the visceral and subcutaneous depots ${ }^{(4)}$. Exposure to ionizing radiation and high cost of computerized tomography scanning to assess body fat make this approach infeasible ${ }^{(6)}$. Measuring the waist circumference (WC) is a convenient, simple and inexpensive means to evaluate this enlargement. To obtain WC, it is necessary to place an inextensible measuring tape all around the abdomen, midway between the top of the hip bone and the bottom of the ribs, after expiration ${ }^{(7)}$. This measurement aids assessment of body composition by indirect determination of abdominal fat ${ }^{(8)}$ and it offers advantages in terms of its ease, precision and execution of the method ${ }^{(9)}$.

However, anthropometric assessments are often very difficult to perform in obese individuals ${ }^{(4)}$. The WC is usually performed at the level of the umbilicus, because to identify the top of the hip bone and the bottom of the ribs may be very difficult. In addition, the drooping abdominal fat may also make it difficult to measure WC. The present study aimed to investigate the sensitivity and applicability of additional measurements in the abdominal region to evaluate the body composition of obese women.

\section{METHODS}

\section{Participants}

This cross-sectional study included 30 obese women with mean age $39.4 \pm 6.3$ years; mean educational level $9.5 \pm 3.7$ years; mean

Declared conflict of interest of all authors: none

Disclosure of funding: This research was supported by Fundação de Amparo à Pesquisa do Estado de São Paulo - FAPESP (research grant process 00273-1) and Conselho Nacional de Desenvolvimento Científico e Tecnológico (CNPq) for the productivity grant given to Diez-Garcia RW.

${ }^{1}$ Universidade de Ribeirão Preto (UNAERP), SP, Brasil. ${ }^{2}$ Hospital Estadual de Sumaré, São Paulo, SP, Brasil. ${ }^{3}$ Pontifícia Universidade Católica de Campinas, Programa de Pós-Graduação em Ciências da Saúde e Faculdade de Nutrição, Campinas, SP, Brasil. ${ }^{4}$ Universidade de São Paulo (USP), Faculdade de Medicina de Ribeirão Preto, Departamento de Ciências da Saúde, Laboratório de Práticas e Comportamento Alimentares - PrátiCA, Ribeirão Preto, SP, Brasil.

Corresponding author: Rosa Diez Garcia. E-mail: wanda@fmrp.usp.br 
number of children $2.2 \pm 1.3$; mean height $157.2 \pm 4.96 \mathrm{~cm}$ and mean BMI $37.3 \pm 4.4 \mathrm{~kg} / \mathrm{m}^{2}$, inpatients of the Clinical Hospital, Ribeirão Preto Medical School, University of São Paulo (HCFMRP-USP). Based on their BMI, 11, 12, and 7 (37, 40, and $23 \%$, respectively) those women exhibited obesity levels I, II, and III, respectively; one of them presented with BMI higher than $50 \mathrm{~kg} / \mathrm{m}^{2}$. The exclusion criteria included: weight above $130 \mathrm{~kg}$, which would limit DXA performance; pregnant women or women with suspected pregnancy; cardiovascular, lung, kidney, liver, or gastrointestinal diseases; diabetes mellitus; women on birth control pills; or who had undergone examinations of the digestive and urinary systems involving contrast agents during the previous two weeks. These exclusion criteria were adopted because, under such conditions, changes in body composition influencing bioimpedance results could occur.

This investigation was approved by the Research Ethics Committee of the Hospital of Ribeirão Preto Medical School.

\section{Anthropometric and body composition analysis}

Weight, BMI, WC at three different points; total and trunk segmental bioelectric impedance (BIA) ${ }^{(10)}$; and dual X-ray absorptiometry (DXA) were measured. The weight was measured on a $300 \mathrm{~kg}$ capacity electronic scale in the morning, after fasting and voiding of the bladder; participants wore light clothes. A two-meter metallic inextensible measuring tape was employed to measure WC. Three WC measurements were standardized: WC1, WC2, and WC3, were measured at the umbilical scar and at 8 and $16 \mathrm{~cm}$ above the umbilical scar, respectively, with the measuring tape placed around the waist. Measures were taken in standing position.

The golden standard method DXA was employed to assess body composition (fat mass, free fat mass, body fat percentage, and trunk fat percentage; the Hologic $4500 \mathrm{~W}$ apparatus was used in this case (Waltham, MA, USA). For this examination, participants wore a hospital gown and laid in the supine position, in the absence of metals, to have their whole body area scanned. Total and trunk bioelectric impedance analysis were conducted using the Biodynamics BIA 450 apparatus, after 12-h fasting. In this case, the participants also lied in the supine position, with legs spread apart and both arms positioned in parallel, away from the trunk; participants wore light clothes, but no shoes or socks. Trunk segmental BIA analysis involved the positioning of a receptor electrode in the medial line of the proximal thigh, in the same plane as the intergluteal cleft; the source electrode was placed $5 \mathrm{~cm}$ away from the receptor electrode. The other receptor electrode was positioned on the manubrium, while the source electrode was placed on the anterior median line of the neck, $5 \mathrm{~cm}$ away from the skull. The trunk length was also measured, as described by Baumgartner et al. ${ }^{(10)}$. To determine the compartments in the trunk segment, the equations reported in Baumgartner et al. ${ }^{(10)}$ were employed (TABLE 1).

TABLE 1. Equations for calculating fat mass (\%) and fat-free mass $(\mathrm{kg})$ for females.

\begin{tabular}{ll}
\hline Parameter & Equation \\
\hline Fat mass (\%) & $\begin{array}{l}17.26+[7.39 \times(\text { body weight } \mathrm{x} \text { trunk } \\
\left.\left.\text { strength } / \text { trunk length }{ }^{2}\right)\right]\end{array}$ \\
Fat-free mass (Kg) & $\begin{array}{l}15.9+0.153 \mathrm{x} \text { trunk length } \mathrm{t}^{2} / \text { impedance } \\
\text { index * }\end{array}$ \\
\hline
\end{tabular}

\footnotetext{
* Impedance index $=$ height $(\mathrm{cm}) 2 /$ total resistance.
}

\section{Statistical analysis}

Pearson correlation $(r)$ was calculated using the software $\mathrm{SAS}^{\circledR} 9.2^{(11)}$. The significance level was set at $95 \%(P<0.05)$. To interpret the Pearson correlation, the following " $\mathrm{r}$ " values were considered: $0.10<r \leq 0.39$, poor correlation; $0.4<r \leq 0.69$, moderate correlation; $0.70<\mathrm{r} \leq 0.89$, strong correlation; and $0.9<\mathrm{r} \leq 10$, very strong correlation $^{(12)}$.

\section{RESULTS}

TABLE 2 shows the characteristics of the study population. Anthropometric measures of body weight, BMI, total and segmental bioelectric impedance of the trunk, abdominal circumference (WC, WC1, WC2) and determination of percentage of fat by DXA were performed.

TABLE 2. Characteristics of the study population.

\begin{tabular}{|c|c|c|}
\hline Parameter & & Average \pm SD \\
\hline Age (years) & & $39.4 \pm 6.3$ \\
\hline Weight (kg) & & $92.17 \pm 11.75$ \\
\hline Stature (m) & & $1.57 \pm 0.05$ \\
\hline $\mathrm{BMI}\left(\mathrm{kg} / \mathrm{m}^{2}\right)$ & & $37.31 \pm 4.37$ \\
\hline \multirow{3}{*}{$\begin{array}{l}\text { Abdominal } \\
\text { Circumference }\end{array}$} & WC (cm) & $111.83 \pm 11.85$ \\
\hline & WC $1(\mathrm{~cm})$ & $104.16 \pm 12.11$ \\
\hline & WC $2(\mathrm{~cm})$ & $98.67 \pm 8.7$ \\
\hline \multirow{3}{*}{ Total BIA } & $\mathrm{FM}(\mathrm{kg})$ & $37.17 \pm 7.45$ \\
\hline & FFM (kg) & $55.00 \pm 5.03$ \\
\hline & $\% \mathrm{GC}$ & $40.03 \pm 3.27$ \\
\hline \multirow{3}{*}{ Total DXA } & FM (kg) & $40.50 \pm 7.71$ \\
\hline & FFM (kg) & $51.67 \pm 6.22$ \\
\hline & $\% \mathrm{BF}$ & $43.73 \pm 4.44$ \\
\hline \multirow{3}{*}{ Trunk BIA } & $\mathrm{FM}(\mathrm{kg})$ & $23.13 \pm 0.84$ \\
\hline & FFM $(\mathrm{kg})$ & $44.08 \pm 3.28$ \\
\hline & $\% \mathrm{TF}$ & $25.40 \pm 2.61$ \\
\hline \multirow{3}{*}{ Trunk DXA } & FM (kg) & $18.69 \pm 3.43$ \\
\hline & FFM (kg) & $24.79 \pm 3.18$ \\
\hline & $\% \mathrm{TF}$ & $42.81 \pm 4.78$ \\
\hline
\end{tabular}

WC: waist circumference measured at the umbilical scar; WC1: waist circumference $8 \mathrm{~cm}$ above WC; WC2: waist circumference $16 \mathrm{~cm}$ above WC; FM: fat mass; FFM: free fat mass; $\%$ BF: body fat percentage; $\% \mathrm{TF}$ : trunk fat percentage.

For total DXA, the present study found strong to moderate correlation between the three WC measurements and fat mass (FM), free fat mass (FFM), and percentage of fat mass ( $\%$ BF). The exception was the correlation between WC3 and \%FM (TABLE 3). As for total BIA, FM, FFM, and $\%$ BF they correlated strongly and moderately with WC1, WC2, WC3, and their sum (TABLE 3).

With regard to correlations between measurements and methods to evaluate trunk segmental body composition, all the WC measurements and their sum correlated strongly and moderately with FM, FFM, and \%TF measured by trunk DXA. The exception was a weak correlation between WC 3 and FFM measured by DXA (TABLE 4). WC measurements and their sum correlated moderately with FM measured by BIA. With respect to FFM and $\%$ TF measured by trunk BIA, they correlated inversely with WC measurements (TABLE 4). 
TABLE 3. Correlation between each waist circumference and total body composition methods, and correlation between the sum of waist circumferences and total body composition methods.

\begin{tabular}{|c|c|c|c|c|c|c|c|c|c|c|c|c|}
\hline & \multicolumn{6}{|c|}{ Total DXA } & \multicolumn{6}{|c|}{ Total BIA } \\
\hline & \multicolumn{2}{|c|}{ FM } & \multicolumn{2}{|c|}{ FFM } & \multicolumn{2}{|c|}{$\% \mathrm{BF}$} & \multicolumn{2}{|c|}{ FM } & \multicolumn{2}{|c|}{ FFM } & \multicolumn{2}{|c|}{$\% \mathrm{BF}$} \\
\hline & $\mathbf{r}$ & $P$-value & $\mathbf{r}$ & $P$-value & $\mathbf{R}$ & $P$-value & $\mathbf{r}$ & $P$-value & $\mathbf{r}$ & $P$-value & $\mathbf{r}$ & $P$-value \\
\hline WC2 & 0.70 & $<0.001 *$ & 0.43 & $0.016^{*}$ & 0.44 & $0.014 *$ & 0.71 & $<0.001 *$ & 0.56 & $0.001 *$ & 0.62 & $<0.001 *$ \\
\hline WC3 & 0.68 & $<0.001 *$ & 0.50 & $0.005 *$ & 0.36 & 0.053 & 0.73 & $<0.001 *$ & 0.57 & $0.001 *$ & 0.64 & $<0.001 *$ \\
\hline
\end{tabular}

WC1: waist circumference measured at the umbilical scar; WC2: waist circumference measured $8 \mathrm{~cm}$ above the umbilical scar; WC3: waist circumference measured $16 \mathrm{~cm}$ above the umbilical scar; FM: fat mass; FFM: free fat mass; $\%$ BF: percentage of body fat. *Significant statistical difference $(P<0.05)$.

TABLE 4. Correlation between each waist circumference and trunk segmental body composition methods, and correlation between the sum of waist circumferences and trunk segmental body composition methods.

\begin{tabular}{|c|c|c|c|c|c|c|c|c|c|c|c|c|}
\hline & \multicolumn{6}{|c|}{ Trunk DXA } & \multicolumn{6}{|c|}{ Trunk BIA } \\
\hline & \multicolumn{2}{|c|}{ FM } & \multicolumn{2}{|c|}{ FFM } & \multicolumn{2}{|c|}{$\% \mathrm{TF}$} & \multicolumn{2}{|c|}{ FM } & \multicolumn{2}{|c|}{ FFM } & \multicolumn{2}{|c|}{$\% \mathrm{TF}$} \\
\hline & $\mathbf{r}$ & $P$-value & $\mathbf{r}$ & $P$-value & $\mathbf{r}$ & $P$-value & $\mathbf{r}$ & $P$-value & $\mathbf{r}$ & $P$-value & $\mathbf{r}$ & $P$-value \\
\hline WC2 & 0.78 & $<0.001 *$ & 0.43 & $0.020 *$ & 0.47 & $0.01 *$ & 0.58 & $0.001 *$ & -0.16 & 0.39 & -0.60 & $<0.001 *$ \\
\hline WC3 & 0.75 & $<0.001 *$ & 0.51 & $0.003^{*}$ & 0.37 & $0.04 *$ & 0.55 & $0.002 *$ & -0.14 & 0.45 & -0.63 & $<0.001 *$ \\
\hline
\end{tabular}

WC1: waist circumference measured at the umbilical scar; WC2: waist circumference measured $8 \mathrm{~cm}$ above the umbilical scar; WC 3 : waist circumference measured $16 \mathrm{~cm}$ above the umbilical scar; FM: fat mass; FFM: free fat mass; \% TF: percentage of trunk fat; $*$ Significant statistical difference $(P<0.05)$.

Correlation analysis between the methods total BIA and total DXA revealed very strong correlation $(\mathrm{r}=0.90, P<0.001)$, strong correlation $(\mathrm{r}=0.84, P<0.001)$, and moderate correlation $(\mathrm{r}=0.54$, $P=0.002$ ) for FM, FFM, and $\% \mathrm{BF}$, respectively. In the case of the correlations between trunk BIA and trunk DXA, results evidenced strong correlation for $\mathrm{FM}(\mathrm{r}=0.70, P<0.001)$, and inverse, weak correlation for both FFM $(\mathrm{r}=-0.22, P=0.24)$ and $\% \mathrm{TF}(\mathrm{r}=-0.08 ; P=0.65)$.

\section{DISCUSSION}

Weight gain and excess adipose tissue accumulation modify the body shape, which hampers the measurement of parameters that help evaluate the nutritional status of obese individuals ${ }^{(13)}$. In this connection, the present cross-sectional study aimed to verify accuracy of the waist measurements proposed. The main result of this investigation was that $\mathrm{WC1}, \mathrm{WC} 2, \mathrm{WC} 3$, and their sum correlated strongly and moderately with the parameters FM, FFM, $\% \mathrm{BF}$, and $\% \mathrm{TF}$ obtained by total and trunk DXA. Therefore, anthropometric measurements, especially waist circumference (WC1, WC2, and WC3), may constitute a sensitive tool to estimate body composition in obese subjects. Wang et al. ${ }^{(3)}$, Tian et al..$^{(13)}$ and Matsushita et al. ${ }^{(14)}$ also reported that waist circumference corresponds to adipose tissue accumulation in severely obese subjects. Hence, WC represents an inexpensive and easily available tool in the clinical setting, as opposed to BIA (a method with intermediate costs) $^{(15)}$ and DXA (which is not easily available and is expensive, despite being the golden standard to assess body composition) ${ }^{(16)}$.

A study ${ }^{(17)}$ that investigated different anthropometric indicators to identify areas of high visceral fat in postmenopausal women has shown that these indicators can replace more sophisticated exams. A recently developed populational study ${ }^{(18)}$ to investigate the effect of body weight, waist circumference and their changes in cardiovascular mortality (among other causes) has shown that weight loss and waist reduction are significantly associated with long-term mortality risk.

Bearing in mind that excess adipose tissue accumulation hinders (i) identification of the anatomical points and (ii) stabilization of the measuring tape around the waist ${ }^{(19)}$, alternative measurements in this region can help reduce the possible errors underlying the nutritional assessment of obese individuals. In the present study, WC1, WC2, WC3, and their sum correlated strongly and moderately with total and trunk DXA. Thus, these measurements constitute an alternative approach in situations where excess abdominal fat prevents measurements of anthropometric parameters.

Different waist measurements and their relationship with trunk or total body adipose tissue have long been explored. Wang et al. ${ }^{(20)}$ used four waist measurements, all recommended by international guidelines, to study a population of men and women with different ethnic backgrounds. All the four measurements started at a certain anatomical bone point in the abdominal region ${ }^{(20)}$. Nonetheless, these reference bone points are not easily accessible in the case of obese subjects. In this work, we proposed using metric reference points to obtain WC2 and WC3, measured from the less complex umbilical scar for WC1. This helped to overcome the aforementioned difficulties and facilitated assessment of obese individuals. Measurements are also age dependent. In the case of older patients, abdominal mass tends to concentrate in lower positions, below the umbilical scar. Measurements above the umbilical scar are intended to provide other measures that can detect variations of abdominal mass in lower positions. 
The importance of the present study is also justified by the need for other measures, due to the difficulties of measurements involving the abdomen in patients with a larger quantity of body fat.

As to the reliability of the different methods used to evaluate obese subjects, the present investigation found good correlation between total DXA and total BIA for the parameters FM, FFM, and $\% \mathrm{BF}$. However, trunk DXA and trunk BIA did not correlate satisfactorily. When reviewed individually, WC1, WC2, and WC3 strongly and moderately correlated with trunk DXA parameters, but $\mathrm{FFM}$ and $\mathrm{TF} \%$ did not correlate with trunk BIA parameters. Jiménez et al. ${ }^{(21)}$ developed equations to estimate total and segmental body composition in severely obese Caucasians. They used eightelectrode mono-frequency BIA and DXA as the reference method to assess a sample consisting of 159 adults. Their findings revealed that BIA overestimated FFM as compared to DXA. In addition, these authors indicated that body segment FM correlated weakly with values determined by DXA. Other studies have used different BIA devices to assess total and segmental body composition. Their authors compared BIA with other methods of body composition analysis and detected discrepancies in BIA analyses ${ }^{(22-25)}$. By investigating common methods of body composition assessment such as DXA and BIA, Tinsley, 2017 ${ }^{(26)}$, pointed out that the degree of disagreement between DXA and BIA varies substantially based on gender and body size.

Some of the limiting factors of applying BIA to evaluate obese and severely obese subjects are as follows: (i) the predictive equations usually target eutrophic individuals ${ }^{(27,28)}$, (ii) obese individuals have a particular body shape, and (iii) obese individuals have altered body water distribution as compared to eutrophic subjects $^{(27,29,30)}$.

In the study of Wang et al., 2018(31), which evaluated the body composition accuracy by multiple frequency bioimpedance compared to dual energy X-ray absorptiometry (DXA) in obese adults, the authors found that the analysis by bioimpedance underestimated the percentage of body fat in men, but overestimated it in women. In addition, this analysis may require correction in the estimation of body composition in obese adults.

Therefore, BIA, especially trunk segmental BIA, is probably more complex to perform in obese individuals, because it requires electrodes repositioning ${ }^{(10)}$. Moreover, compared with DXA, trunk BIA provides less accurate trunk composition analysis in obese individuals. In our study, we found that WC1, WC2, and WC3 correlated well with trunk DXA, so we believe that these measurements constitute an efficient and accurate means to obtain the central segmental evaluation of obese women. The measurements are important as they can better represent the areas of greater fat concentration and the shape of the body that are associated with the risk. These measures do not apply to the diagnosis of degrees of obesity. A study investigating waist circumference (WC) and the visceral fat area in overweight and obese adults has shown that WC can be a moderate predictor of visceral fat and provides a feasible measure for estimating glucose metabolic risks ${ }^{(32)}$. The difficulties in performing measurements and evaluation of body composition, in obesity, increase with increased body volume and with the specifics of body shape. The follow up of changes in body shape associated with weight gain that reflect body composition with metric tape measurements, could facilitate the monitoring of nutritional status. It is important to emphasize the importance of additional measures that can help monitor shape and weight gain, reflecting body composition, as shown in other studies in the relevant literature, such as body adiposity index ${ }^{(33)}$. Another point to be highlighted is the concern in connection with shape, weight and clinical implications; these are aspects; which have been studied by our research group ${ }^{(34-37)}$.

In the case of obese women, the present results demonstrated that the proposed measurements (WC2, WC3, and the sum of three abdominal points) strongly correlate with body composition parameters assessed by trunk and total DXA. Hence, these measurements are good indicators of trunk and body fat, and are even more satisfactory than total and segmental BIA parameters, because they exhibit better correlation in the golden standard method (DXA). These waist circumference measurements may provide more accurate evaluation, especially in the case of body shapes modified by fat accumulation in the abdominal region and gravity effects. The differential of the present study is to propose and to have available simplified and low cost measures that bring more information about the distribution of abdominal fat and obesity of these patients. This investigation may reinforce the importance of monitoring weight gain associated with body shape, with the proposed measures. The study needs to be expanded to include patients of different ages, heights, and BMI ranges.

\section{Limitations of the study}

The study cross-sectional design and sample size can be considered as limiting factors. Another factor to be considered is the fact that cut-off points were not considered in the present study so that the anthropometric measurements could reflect the abdominal fat accumulation levels. Therefore, other investigations are necessary in order to further explore this relationship. Another limitation is the fact that patients' height was not standardized, as this criterion would greatly limit the study sample size.

\section{ACKNOWLEDGEMENTS}

This study was carried out at Clinic Hospital of Ribeirão Preto, São Paulo, Brazil.

\section{Authors' contribution}

Triffoni-Melo AT was the principal investigator and contributed to the study design, data collection, data analyses, interpretation of the findings and wrote the manuscript; Monte-Alegre FA contributed to the data collection, interpretation of the findings and writing of the manuscript; Leandro-Merhi VA contributed to the discussion and writing of the manuscript; Diez-Garcia RW was coordinator of project and contributed to the study design, data analyses, interpretation of the findings and writing of the manuscript. All authors read and approved the final version of the manuscript.

\section{Orcid}

Andresa de Toledo Triffoni-Melo. Orcid: 0000-0002-8940-3783.

Flávia de Andrade Monte-Alegre. Orcid: 0000-0002-8301-5667. Vania Aparecida Leandro-Merhi. Orcid: 0000-0002-2623-6471. Rosa Wanda Diez-Garcia. Orcid: 0000-0002-7062-974X. 
Triffoni-Melo AT, Monte-Alegre FA, Leandro-Merhi VA, Diez-Garcia RW. Medidas abdominais adicionais são uma ferramenta útil para avaliar a composição corporal em mulheres obesas. Arq Gastroenterol. 2019;56(3):294-9.

RESUMO - Contexto - O acúmulo de tecido adiposo excessivo no ganho de peso se dá em maior proporção no segmento do tronco, leva à alteração dos formatos corporais dificultando a tomada de medidas antropométricas, em especial a circunferência abdominal (CA). Objetivo - Avaliar a sensibilidade de medidas adicionais na região abdominal, considerando cada medida individualmente e sua somatória, e a aplicabilidade dessas medidas na avaliação da composição corporal de mulheres obesas. Métodos - Foram avaliadas 30 mulheres com idade entre 20 e 50 anos e IMC acima de $30 \mathrm{~kg} /$ $\mathrm{m}^{2}$ com a realização de três medidas de CA denominadas: CA1 padronizada na cicatriz umbilical, CA2 a $8 \mathrm{~cm}$ acima da cicatriz umbilical e CA3 a $16 \mathrm{~cm}$ acima da cicatriz umbilical. Foi avaliada a correlação (r) destas medidas antropométricas e de sua somatória com os parâmetros massa gorda (MG), massa livre de gordura (MLG), porcentagem de gordura corporal (\%GC) e do tronco $(\% \mathrm{GT})$ obtidos por impedância bioelétrica (BIA) total e segmentar do tronco e por absorciometria de raios-X de dupla energia (DXA) total e do tronco, como padrão ouro. Resultados - As medidas CA1, CA2, CA3 e a somatória das três tiveram correlação forte e moderada com os parâmetros MG, MLG e \%GC tanto para BIA total como para DXA total e DXA do tronco. Conclusão - Os resultados deste estudo mostram forte correlação entre a soma das medidas de três pontos no abdome com DXA de tronco e total, em mulheres obesas, sugerindo serem estas medidas, um bom indicador de gordura corporal e de gordura da região do tronco, superior aos resultados obtidos por BIA. O uso dessas três medidas pode ser um indicador alternativo de avaliação da gordura corporal e de tronco, nos casos em que o formato corporal de acúmulo de gordura na região do tronco, dificultar a acurácia da medida clássica (CA1).

DESCRITORES - Obesidade. Mulheres. Circunferência abdominal. Composição corporal. Absorciometria de fóton. Abdome. Precisão da medição dimensional. Impedância elétrica.

\section{REFERENCES}

1. Flegal KM, Carroll MD, Ogden CL, Curtin LR. Prevalence and trends in obesity among US adults, 1999-2008. JAMA. 2010;303:235-41.

2. Bigaard J, Frederiksen K, Tjonneland A, Thomsen BL, Overvad K, Heitmann BL, Sørensen TI. Waist circumference and body composition in relation to allcause mortality in middle-aged men and women. Int J Obes. 2005;29:778-84.

3. Wang J, Gallagher D, Thornton JC, Yu W, Weil R, Kovac B, Pi-Sunyer FX Waist Circumference, and Percentage Fat in Severely Obese Adults. Obesity. 2007; 15:2688-98.

4. Das SK. Body composition measurement in severe obesity. Curr Opin Clin Nutr Metab Care 2005;8:602-6.

5. Machann J, Horstmann A, Born M, Hesse S, Hirsch FW. Diagnostic imaging in obesity. Best Pract Res Clin Endocrinol Metab. 2013;27:261-77.

6. Baumgartner RN, Heymsfield SB, Roche AF, Bernardino M. Abdominal composition quantified by computed tomography. Am J Clin Nutr. 1988;48:936-45.

7. World Health Organization, WHO (2008) Waist circumference and waist-hip ratio. Report of a WHO Expert Consultation. WHO Library Cataloguing-in-Publication Data. Geneva, Switzerland.

8. Vianna CA, da Silva Linhares R, Bielemann RM, Machado EC1, González-Chica DA, Matijasevich AM, et al. Accuracy and adequacy of waist circumference cut-off points currently recommended in Brazilian adults. Public Health Nutr. 2013;17:1-9.

9. Seimon RV, Wild-Taylor AL, Gibson AA, Harper C, McClintock S, Fernando HA, et al. Less Waste on Waist Measurements: Determination of Optimal Waist Circumference Measurement Site to Predict Visceral Adipose Tissue in Postmenopausal Women with Obesity. Nutrients. 2018;10(2). doi:10.3390/nu10020239.

10. Baumgartner RN, Chumlea WC, Roche AF. Estimation of body composition from bioelectric impedance of body segments. Am J Clin Nutr. 1989;50:221-6.

11. SAS Institute Inc. (2002). SAS/STAT ${ }^{\circledR}$ User's Guide, Version 9, Cary, NC, USA: SAS Institute Inc.

12. Bryman A, Cramer D. Quantitative data analysis with IBM SPSS 17,18 \& 19 A Guide for Social Scientists, 1st edition. Routledge, London. (2011).

13. Tian S, Mioche L, Denis JB, Morio B. A multivariate model for predicting segmental body composition. Br J Nutr. 2013;110:2260-70.

14. Matsushita Y, Nakagawa T, Shinohara M, Yamamoto S, Takahashi Y, Mizoue $\mathrm{T}$, et al. How can waist circumference predict the body composition? Diabetol Metabol Syndr. 2014;6:11

15. Kushner RF. Bioelectrical impedance analysis: a review of principles and applications. J Am Coll Nutr. 1992;11:199-209.

16. Lukaski HC. Methods for the assessment of human body composition: traditional and new. Am J Clin Nutr. 1987;46:537-56.
17. Gondim Pitanga FJ, Seara Pitanga CP, Calçada Dias Gabriel RE, Cristina Beck $\mathrm{C}$, Rodrigues Moreira MH. Anthropometry to identify high visceral fat area in postmenopausal women. Nutr Hosp. 2015;32:2535-9.

18. Lee WJ, Peng LN, Loh CH, Chen LK. Effect of body weight, waist circumference and their changes on mortality: a 10-year population-based study. J Nutr Health Aging. 2018;22:959-64.

19. Barber J, Palmese L, Chwastiak LA, et al. Reliability and Practicality of Measuring Waist Circumference to Monitor Cardiovascular Risk Among Community Mental Health Center Patients. Community Ment Health J. 2014;50:68-74.

20. Wang J, Thornton JC, Bari S, Williamson B, Gallagher D, Heymsfield SB, et al. Comparisons of waist circumferences measured at 4 sites. Am J Clin Nutr. 2003;77:379-84

21. Jiménez A, Omaña W, Flores L, Coves MJ, Bellido D, Perea V, Vidal J. Prediction of whole-body and segmental body composition by bioelectrical impedance in morbidly obese subjects. Obes Surg. 2012;22:587-93.

22. Lazzer S, Boirie Y, Meyer M, Vermorel M. Evaluation of two-to-foot bioelectrical impedance analysers to assess body composition in overweight and obese adolescents. Br J Nutr. 2003;90:987-92.

23. Sun G, French CR, Martin GR, Younghusband B, Green RC, Xie YG, et al. Comparison of multifrequency bioelectrical impedance analysis with dual-energy $\mathrm{X}$-ray absorptiometry for assessment of percentage body fat in a large, healthy population. Am J Clin Nutr. 2005;81:74-8.

24. Neovius M, Hemmingsson E, Freyschuss B, Uddén J. Bioelectrical impedance underestimates total and truncal fatness in abdominally obese women. Obesity. 2006;14:1731-8.

25. Lazzer S, Bedogni G, Agosti F, De Col A, Mornati D, Sartorio A. Comparison of dual-energy X-ray absorptiometry, air displacement plethysmography and bioelectrical impedance analysis for the assessment of body composition in severely obese Caucasian children and adolescents. Br J Nutr. 2008;100 918-24.

26. Tinsley GM. Proportional bias between dual-energy x-ray absorptiometry and bioelectrical impedance analysis varies based on sex in active adults consuming high- and low-carbohydrate diets. Nutrition Research. 2017;42:85-100.

27. Wells JC, Fuller NJ, Dewit O, Fewtrell MS, Elia M, Cole TJ. Four-component model of body composition in children: density and hydration of fat-free mass and comparison with simpler models. Am J Clin Nutr. 1999;69:904-12.

28. Stewart SP, Bramley PN, Heighton R, Green JH, Horsman A, Losowsky MS, Smith MA. Estimation of body composition from bioelectrical impedance of body segments: comparison with dual-energy X-ray absorptiometry. Br J Nutr. 1993;69:645-55 
29. Waki M, Kral JG, Mazariegos M, Wang J, Pierson RN Jr, Heymsfield SB. Relative expansion of extracellular fluid in obese vs. nonobese women. Am J Physiol. 1991;261:199-203.

30. Deurenberg P. Limitations of the bioelectrical impedance method for the assessment of body fat in severe obesity. Am J Clin Nutr. 1996;64:449-52.

31. Wang ZH, Yang ZP, Wang XJ, Dong YH, Ma J. Comparative Analysis of the Multi-Frequency Bio-impedance and Dual-energy X-ray Absorptiometry on Body Composition in Obese Subjects. Biomed Environ Sci. 2018;31:72-5.

32. Li X, Katashima M, Yasumasu T, Li KJ. Visceral fat area, waist circumference and metabolic risk factors in abdominally obese Chinese adults. Biomed Environ Sci. 2012;25:141-8

33. Alvim Rde O, Mourao-Junior CA, de Oliveira CM, Krieger JE, Mill JG, Pereira AC. Body mass index, waist circumference, body adiposity index, and risk for type 2 diabetes in two populations in Brazil: general and Amerindian. PLoS One. 2014;9:e100223.
34. Penaforte FRO, Japur CC, Diez-Garcia RW, Chiarello PG. Upper trunk fat assessment and its relationship with metabolic and biochemical variables and body fat in polycystic ovary syndrome. J Hum Nutr Diet. 2011;24:39-46.

35. Penaforte FRO, Japur CC, Diez-Garcia RW, Macedo CSV, Chiarello PG. The use of body circumferences for the prediction of intra-abdominal fat in obese women with polycystic ovary syndrome. Nutrición Hospitalaria. 2012;27: 1662-6.

36. Mialich MS, Martinez EZ, Diez-Garcia RW, Jordão Junior AA. New body mass index adjusted for fat mass (BMIfat) by the use of electrical impedance. Int $\mathbf{J}$ Body Compos Res. 2011;9:65-72.

37. Triffoni-Melo AT, Santos RCL dos, Diez-Garcia RW. Effect of weight and body composition changes on waist measurement of severely obese women receiving carbohydrate-restricted diet. Revista de Nutrição. 2014;27:5-13. 